\title{
RURAL HOUSEHOLD HEALTH CARE UTILIZATION AND ITS DETERMINANTS IN INDIAN STATE OF KERALA: CROSS SECTIONAL EVIDENCE
}

\author{
Anu Joseph ${ }^{1}$ and C. Krishnan ${ }^{2}$ \\ ${ }^{1}$ Research scholar, Department of Economics, Govt college Kodencheri, Calicut \\ ${ }^{2}$ Professor and Dean, Department of Development Studies, Central University of South Bihar \\ DOI: 10.46609/IJSSER.2021.v06i07.036 URL: https://doi.org/10.46609/IJSSER.2021.v06i07.036
}

\begin{abstract}
This paper empirically investigates the determinants of health care utilization in Indian state of Kerala. While asserting that health constitutes the bedrock of a person, its preservation and case to case analysis and utilization on its determinants markedly influence the rural health care . The paper corroborates that the variables such as food expenditure, income, no of elderly in a family, family size, no of children and education in one way or the other determine the utilization of health care.
\end{abstract}

Keywords: Health care utilization, Rural health care, Determinants, Kerala, India

JEL Classification: I112,I113, I113,I114

\section{Introduction}

In an economic perspective, an individual's propensity to utilise health care is determined by the costs of utilisation and the perceived benefits of health care. Since costs are mainly determined by the allocation of health care resources, utilisation will in practice be determined by the interaction between demand and provision of health care (McGuire et al 1988). The provision of health care determines the availability of health care resources. The price of health care is occasionally a result of "market outcome", but more commonly the government regulates it. Similarly, public policies often determine the location of facilities, budgets, waiting times etc. 


\section{International Journal of Social Science and Economic Research}

ISSN: $2455-8834$

Volume:06, Issue:07 "July 2021"

Demand for health care, on the other hand, depends on several factors of which some are interrelated. The individual's attitudes, perceptions and decisions are important determinants of health care utilization. The influential factors on demand for health care are health status, income and education (Grossman, 1972; Manning et al 1987; Kenkel, 1994). An individual's health status will of course greatly affect hers or his perceived benefit of medical treatment. However, perceived benefit is also influenced by education. Individuals from households headed by an individual with secondary level of education or higher were more likely to seek health care(Ashoken,2009). Income is important since it determines ability to pay and it influences earnings foregone when seeking care. Benefits and costs of treatment may be expected to vary with age and gender, e.g., because of differences in health status and work productivity. Finally, individuals differ in preferences, i.e. personal taste, and to the extent that education influences preferences this may lead to systematic socio-economic differences.

Many decisions are household decisions. This means that the utilisation of individual household members depend on household factors, including relation to other household members and their characteristics. The family can be viewed as the producer of health rather than the individual (Jacobson, 1999; Bolin et al, 1999), and utilisation of health care depends on household income etc. Furthermore, decisions are influenced by several intra-household factors. It has been shown that the education of the member of a household has an influence on the other household members' health-related behaviour, such as health care utilisation (Currie and Gruber, 1996; Thomas et al, 1991).

Kerala has a significant record in the health sector, famously known as the Kerala paradox of economic backwardness \& social development(K.P Kannan,2005). Kerala has the best basic health indices among the Indian States and it is comparable with the developed countries((NFHS-3 India,2005-06). These include low birth rates, higher female sex ratio, low infant mortality and high life expectancy. The priority given by the society and the administration to health related issues dates back to pre independence era during which Kerala was ahead of other states at the time of Indian independence thanks to high levels of literacy, female literacy and autonomy, social reforms such as the land reforms, a political climate favouring the rights of the poor and underprivileged, and high public expenditure in social sectors such as education and health. However these achievements have been at a plateau in recent years. For instance Infant Mortality Rate has not been able to touch single digits despite hovering between 10 and 15 for nearly 10 years now.Even though the mortality rates in Kerala are low, the morbidity rates are pretty high and aged people are 10.5 percent of Kerala's population(Census,2011) which has been attributed to the heightened awareness and 
health seeking behaviour, and utilization of health care. It should be noted that further development of Kerala and achievement of the public health targets of health related Millennium Development Goals is impossible without addressing the social determinants.

Most of the research on utilisation of health care has concentrated on the individual as the consumer of health. However much speaks for viewing the household as the main producer of health and consumer of health care. This may be even more important to take into account when analysing utilisation in India, particularly in Kerala, where the family union is stronger and the dependency ratio higher. Therefore, it is deemed desirable to explore the determinants of health care expenditure at household level in Kerala.

\section{Methodology of the Study}

The present study is based on randomly selected 100 cross section units from ward 13 of Kumaramputhur Panchayat of Palakkad district of Kerala. The study used OLS method to find out the determinants of household expenditure on health care. The dependent variable used in the analysis is the household's total yearly health care expenditure and the independent variables are expenditure on food, income of households, number of elderly members, family size, number of children, education of household head.

The model specification has been presented below:

$$
\mathbf{y}=\boldsymbol{\alpha}+\boldsymbol{\beta}^{\prime} \mathbf{x}+\mathbf{u}
$$

where, $y=$ household expenditure on health care and

$\beta^{\prime}=$ vector of all the explanatory variables and $\mathrm{u}=$ the error term.

The complete model is as follows:

expH= $\alpha+\beta_{1}$ Expend.F $+\beta_{2}$ Incom $+\beta_{3}$ No.eld $+\beta_{4}$ No.Family $+\beta_{5}$ No.child $+\beta_{6}$ Educ + u..............................(2)

The table below presents the description of the variables. 
International Journal of Social Science and Economic Research

ISSN: 2455-8834

Volume:06, Issue:07 "July 2021"

\section{Description of Variables}

Variable

Exp.H

Expend.F

Income

No.eld

No.family

No.child

Educ

\section{$\underline{\text { Description }}$}

= household expenditure on health care(Yearly)

= household expenditure on food

= yearly income of the households

= number of elderly people in the households

= number of household members

$=$ number of children

= educational qualification of household head (a dummy variable constructed by assigning value $1=$ above secondary education; $0=$ below secondary education)

$\alpha=$ constant, $\beta_{1}, \beta_{2}, \beta_{3}, \beta_{4}, \beta_{5}, \beta_{6}$, are coefficients

\section{Empirical Analysis}

\section{Profile of the respondents}

The socio-demographic profile of rural sample households are given in table 5.1.As shown in table 5.1, the majority of households have a male as head of household, 75.24 percent, and the female headed families are only 24.76 in this sample survey. The majority of heads of household are married, 77.22 percent, while the rest either have never been married, are separated, divorced or widowed. As far as Religion is concerned, the study shows that 77.0 percent of the sample households were Hindus and 14.8 percent followed Muslims and 28.9 percent Christians. Interestingly, caste wise, in the study area almost equal number of households belonged to SC/ST and OBC (41.5\% and 44.5\% respectively) and the remaining 14 percent were General. The majority of the family in the sample households are nuclear family and also $55 \%$ of respondents are under above poverty line and $45 \%$ of households are under below poverty line. This result indicate that rural poverty too severe in the study area. Another interesting feature of this study is that migration among the rural households are too low in this sample. It was only 7.9 percentage of households having one or more members who are working at abroad. 
International Journal of Social Science and Economic Research

ISSN: 2455-8834

Volume:06, Issue:07 "July 2021"

Table 1

Socio-demographic characteristics of rural households

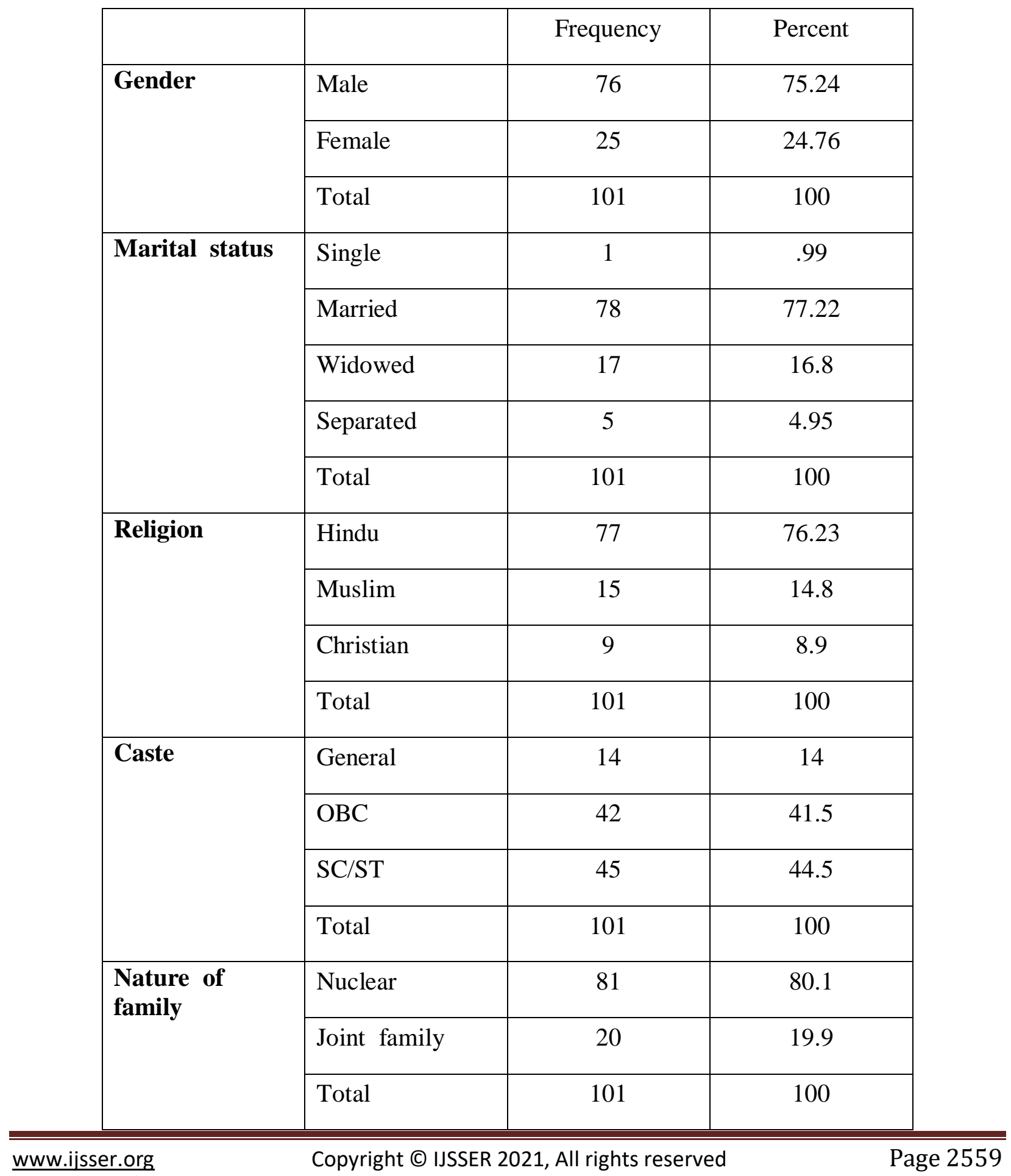


International Journal of Social Science and Economic Research

ISSN: 2455-8834

Volume:06, Issue:07 "July 2021"

\begin{tabular}{|l|l|c|c|}
\hline $\begin{array}{l}\text { Household } \\
\text { member } \\
\text { working in } \\
\text { abroad }\end{array}$ & Yes & 8 & 7.9 \\
\cline { 2 - 4 } & No & 93 & 92.1 \\
\cline { 2 - 4 } & Total & 101 & 100 \\
\hline Family status & BPL & 46 & 45 \\
\cline { 2 - 4 } & APL & 101 & 55 \\
\cline { 2 - 4 } & Total & 55 & 100 \\
\hline
\end{tabular}

Source : Primary Survey

The study reveals that nearly 75 percentages of household heads secured secondary and higher education. The figure indicates that $42.57 \%$ of respondents having secondary education, $13.86 \%$ respondents secured higher secondary and 12.75 having higher education. The study also show that $4.95 \%$ of sample respondents do not having any formal education.

As far as employment status is concerned, the study indicates that $70.31 \%$ of household heads are employed and remain percentages are either unemployed or out of labour force.

Among the 74 employed sample respondents 41 sample respondents were working as wage employers and 9 respondents running business, 22 respondents were salaried. Remaining 2 samples are self employer and farmer. The results can see from the table 5.2 and figure 5.1

Table 2

Educational and employment status of respondents

\begin{tabular}{|l|l|c|c|}
\hline & & Frequency & Percent \\
\hline $\begin{array}{l}\text { Educational } \\
\text { status }\end{array}$ & No formal education & 5 & 4.9 \\
\cline { 2 - 4 } & Primary & 26 & 25.74 \\
\cline { 2 - 4 } & Secondary & 43 & 42.57 \\
\cline { 2 - 4 } & Higher secondary & 14 & 13.86 \\
\cline { 2 - 4 } & Higher education & 13 & 12.75 \\
\hline
\end{tabular}


International Journal of Social Science and Economic Research

ISSN: 2455-8834

Volume:06, Issue:07 "July 2021"

\begin{tabular}{|l|l|c|c|}
\hline \multirow{4}{*}{$\begin{array}{l}\text { employment } \\
\text { status }\end{array}$} & Total & 101 & 100 \\
\cline { 2 - 4 } & Employed & 71 & 70.31 \\
\cline { 2 - 4 } & Unemployed & 29 & 28.70 \\
\cline { 2 - 4 } & Totired & 1 & .9 \\
\hline \multirow{4}{*}{$\begin{array}{l}\text { economic } \\
\text { activity of } \\
\text { household head }\end{array}$} & Wage employment & 41 & 100 \\
\cline { 2 - 4 } & Running business & 9 & 40.5 \\
\cline { 2 - 4 } & Self employment & 1 & .9 \\
\cline { 2 - 4 } & Farming & 1 & .9 \\
\cline { 2 - 4 } & Salaried & 22 & 21.78 \\
\cline { 2 - 4 } & Total & 74 & 66.7 \\
\cline { 2 - 4 } & Not working & 27 & 24.3 \\
\hline
\end{tabular}

Source : Primary Survey

The households are receiving income from different sources. But income from employment is prime source of households. The study results given in the table 5.3 shows that $84.16 \%$ of households are deriving income employment and 12.28 percentage respondents reported income from business and 2.28 percentage households prime source of income is income from physical assets.

Table 3

Households Source of income

\begin{tabular}{|l|c|c|}
\hline Source of income & Frequency & Percent \\
\hline Income from employment & 85 & 84.16 \\
\hline Income from business & 13 & 12.28 \\
\hline
\end{tabular}


International Journal of Social Science and Economic Research

ISSN: 2455-8834

Volume:06, Issue:07 "July 2021"

\begin{tabular}{|l|c|c|}
\hline Income from physical asset & 3 & 2.28 \\
\hline Total & 101 & 100 \\
\hline
\end{tabular}

Source : Primary Survey

In the table 5.4, the households' income and remittances are summarized. The table reveals that average monthly income of the households in the study rupee 15742.5743 and the minimum amount of monthly income in the households rupee 6000.00 and maximum 60000 .

The mean income of household head is Rs. 9051.8218 and maximum monthly income of households head is 60000.00 and zero is the minimum. This show that there are many households who are not having income in the study area.

In this study migrants households are relatively low, only 7.9 percent of households have one or more members who are working abroad. The mean foreign remittances received by the households are 8390.6364.

Table 4

Descriptive statistics of households' income, remittances

\begin{tabular}{|l|c|c|c|c|}
\hline \multicolumn{5}{|c|}{ DESCRIPTIVE STATISTICS } \\
\hline & & $\begin{array}{c}\text { Amount of } \\
\text { remittance }\end{array}$ & $\begin{array}{c}\text { Monthly income } \\
\text { of the household }\end{array}$ & $\begin{array}{c}\text { Monthly income of } \\
\text { household head }\end{array}$ \\
\hline & $\mathrm{N}$ & 11 & 101 \\
\cline { 2 - 5 } & \multicolumn{5}{|c|}{} \\
\hline Mean & 8390.6364 & 15742.5743 & 9051.8218 \\
\hline Std. Deviation & 6128.61190 & 8901.29593 & 9147.96090 \\
\hline Minimum & 0 & 6000.00 & 0 \\
\hline Maximum & 15000.00 & 60000.00 & 60000.00 \\
\hline
\end{tabular}

Source : Estimated from sample survey 
There are different age composition of members of the household. Age compositions of household members are one the influential factor of health care utilization among households. For simplicity, this study categorized household members into different groups. They are: elderly people ; adults; children; fertile aged group women; total number of household members

The presence of elderly people are one of the important determinants of health care expenditure among households. Since the health economics literatures clearly indicates positive association between aged people and health care utilization. Elderly people are one of the important composition of Kerala's Population. According to the Census 2011 provisional report, 10.5 of our populations are elderly in Kerala. Therefore it is essential to understand the number of aged people in the households. In our study 48.5 percentage of sample households having at least one or more aged members. The table 5.4 shows that 36.6 percentage of households having one aged member, 9 percentage households having two aged members and 1.9 percent households having three aged members and 51.5 percent of households have no burden of elderly people.

The table 5.4 also shows the adult numbers among households. It shows that 45.45 percent of households have two adults, 24.4 percent have three adults, 19.19 percent have four adult members in households. The study reveals that 74 percent of households have no fertile age group women and only 16 percent of households have one fertile age group women.

Table 5

Composition of household population

\begin{tabular}{|l|c|c|}
\hline Number of elderly people & Frequency & Percent \\
\hline Size & & \\
\hline 1 & 37 & 36.6 \\
\hline 2 & 10 & 9 \\
\hline 3 & 2 & 1.9 \\
\hline Total & 49 & 48.5 \\
\hline No elderly & 52 & 51.5 \\
\hline Number of adults & Frequency & Percent \\
\hline
\end{tabular}


International Journal of Social Science and Economic Research

ISSN: 2455-8834

Volume:06, Issue:07 "July 2021"

\begin{tabular}{|l|c|c|}
\hline 1 & 8 & 8.08 \\
\hline 2 & 45 & 45.45 \\
\hline 3 & 24 & 24.24 \\
\hline 4 & 19 & 19.19 \\
\hline 5 & 1 & 1.01 \\
\hline 6 & 2 & 2.03 \\
\hline Total & 99 & 100 \\
\hline $\begin{array}{l}\text { Numbe groups } \\
\text { agoman in fertile }\end{array}$ & Frequency & Percent \\
\hline 1 & 17 & 16 \\
\hline No fertile age group women & 84 & 74 \\
\hline Total & 101 & 100 \\
\hline
\end{tabular}

Source : Primary Survey

The mean number of elderly household members are 1.28 and the minimum number of elderly in household is 1 and maximum number is 3 and the standard deviation is 0.54 , which show the variability in sample.. The average number of children below the age of 15 years in households are 1.78 and the minimum number of children in household are 1 and maximum 4 and standard deviation is 0.69 . The mean number of adults were 2.65 , one for fertile aged group women and the average household members were 4.28 and other descriptive statistics of these variable can see in table 5.5 
International Journal of Social Science and Economic Research

ISSN: 2455-8834

Volume:06, Issue:07 "July 2021"

Table 6

Descriptive statistics of age composition of household population

\begin{tabular}{|l|l|l|l|l|l|l|}
\hline \multicolumn{7}{|c|}{ DESCRIPTIVE STATISTICS } \\
\hline \multirow{2}{*}{} & $\begin{array}{l}\text { Descriptive } \\
\text { statistics }\end{array}$ & $\begin{array}{l}\text { Number } \\
\text { of elderly } \\
\text { people in } \\
\text { the } \\
\text { household }\end{array}$ & $\begin{array}{l}\text { Number of } \\
\text { children in } \\
\text { the } \\
\text { household }\end{array}$ & $\begin{array}{l}\text { Number of } \\
\text { adults in } \\
\text { the } \\
\text { household }\end{array}$ & $\begin{array}{l}\text { Number of } \\
\text { woman in } \\
\text { fertile age } \\
\text { groups }\end{array}$ & $\begin{array}{l}\text { Total } \\
\text { number of } \\
\text { the } \\
\text { household }\end{array}$ \\
\hline N & Number & 49 & 58 & 99 & 17 & 101 \\
\cline { 2 - 7 } & $\begin{array}{l}\text { Not in } \\
\text { households }\end{array}$ & 62 & 53 & 12 & 94 & 10 \\
\hline Mean & 1.2857 & 1.7931 & 2.6566 & 1.0000 & 4.2871 \\
\hline Std. Deviation & 1.00 & 1.00 & 1.00 & 1.00 & 1.00 \\
\hline Minimum & 3.00 & 4.00 & 6.00 & 1.00 & 10.00 \\
\hline Maximum & & & & & \\
\hline
\end{tabular}

Source : Estimated from sample survey

\section{Expenditure on Health Care among Households}

\section{Expenditure of households}

The households are utilizing their income on many purposes. The important expenditures of the rural households are- expenditure on food and non-food items. Among the non-food expenditure, expenditure on health is one of the important one. For simplicity, the study categorized household expenditure into: total households expenditure, total expenditure on food, total expenditure other than food and total expenditure on health. The descriptive statistics of different households expenditures are summarized in table 5.7

As shown in table, The average monthly total expenditure of households are 9099.0099 members are 1.28 and the minimum number of elderly in household is 1 and maximum number 
is 3 and the standard deviation is 0.54 ,which show the variability in sample.. The average number of children below the age of 15 years in households are 1.78 and the minimum number of children in household are 1 and maximum 4 and standard deviation is 0.69 . The mean number of adults were 2.65, one for fertile aged group women and the average household members were 4.28 and other descriptive statistics of these variable can see in table 5.5

Table 7

\section{Descriptive statistics of households expenditures}

\begin{tabular}{|c|c|c|c|c|}
\hline \multicolumn{5}{|c|}{ Descriptive statistics } \\
\hline & $\begin{array}{l}\text { Monthly total } \\
\text { expenditure of } \\
\text { household }\end{array}$ & $\begin{array}{l}\text { Monthly } \\
\text { total } \\
\text { expenditure } \\
\text { on health }\end{array}$ & $\begin{array}{l}\text { Monthly } \\
\text { total } \\
\text { expenditure } \\
\text { on food }\end{array}$ & $\begin{array}{l}\text { Monthly total } \\
\text { expenditure } \\
\text { other than food }\end{array}$ \\
\hline $\mathrm{N}$ & 101 & 101 & 101 & 101 \\
\hline Mean & 9099.0099 & 2375.2475 & 2617.8218 & 4297.0297 \\
\hline Std. Deviation & 4252.65788 & 2376.10631 & 738.43023 & 3030.13054 \\
\hline Minimum & 1000.00 & 500.00 & 1000.00 & 500.00 \\
\hline Maximum & 30000.00 & 20000.00 & 4500.00 & 16000.00 \\
\hline
\end{tabular}

Source : Estimated based sample survey

\section{Important health problems among households}

Households have been suffering many health problems. This is clear from the table 5.8.The table clearly shows that households have suffering a multiple health problems. Therefore, the researcher has used multiple response analysis. In the table, the cell $\mathbf{N}$ under Responses is the number of positive responses for each item. The percent of responses is the overall percentage. The percent of cases is the percentage for individual item. In The table $\mathrm{N}$ column shows that positive responses are high for other diseases(78), sugar (37) and all other health problems are more or less equally distributed. As far as percentage responses are concerned, other health 
International Journal of Social Science and Economic Research

ISSN: 2455-8834

Volume:06, Issue:07 "July 2021"

problems $(39.8 \%$ ) and sugar(18.9\%) have highest percentages of total and skin and heart problems are very low compare to other health problems and their percentages are 5.6\% each.

Table 8

Important health problems among households

\begin{tabular}{|c|l|c|c|c|}
\hline \multirow{2}{*}{$\begin{array}{l}\text { No. } \\
\end{array}$} & \multirow{2}{*}{ Health problems } & Responses & & \\
\cline { 2 - 4 } & & $\mathbf{N}$ & Percent & Percent of Cases \\
\hline 1 & Sugar & 37 & $18.9 \%$ & $36.6 \%$ \\
\hline 2 & Blood pressure & 14 & $7.1 \%$ & $13.9 \%$ \\
\hline 3 & Cholesterol & 17 & $8.7 \%$ & $16.8 \%$ \\
\hline 4 & Skin problem & 11 & $5.6 \%$ & $10.9 \%$ \\
\hline 5 & Allergy & 16 & $8.2 \%$ & $15.8 \%$ \\
\hline 6 & Heart problem & 11 & $5.6 \%$ & $10.9 \%$ \\
\hline 7 & Age problem & 12 & $6.1 \%$ & $11.9 \%$ \\
\hline 8 & Others & 78 & $39.8 \%$ & $77.2 \%$ \\
\hline & Total & 196 & $100.0 \%$ & $194.1 \%$ \\
\hline
\end{tabular}

Source : Primary Survey

Types of health expenditure among households

In the table 5.9 and 5.10 given below, the households' expenditure on health care are summarized. In the study the researcher examined three important types of health expenditure. They are expenditure on medicine, hospital fees, surgery. The multiple response table 5.9 reveals that expenditure on Medicines and hospital fee are the most important expenditures of households in the study area. The study indicated that households responses on expenditure on medicine and hospital fee are $47.2 \%$ each . But expenditure on surgery is too low, it is only just 5.6 percent response received on it. 
International Journal of Social Science and Economic Research

ISSN: 2455-8834

Volume:06, Issue:07 "July 2021"

Table 9

Different types of health expenditure among households

\begin{tabular}{|l|l|r|r|r|}
\hline $\begin{array}{l}\text { SL } \\
\text { No. }\end{array}$ & $\begin{array}{l}\text { Different health expenditures } \\
\text { among households }\end{array}$ & N & Percent & Percent of Cases \\
\hline 1 & Expenditure of medicine & 101 & $47.2 \%$ & $100.0 \%$ \\
\hline 2 & Expenditure of hospital fee & 101 & $47.2 \%$ & $100.0 \%$ \\
\hline 3 & Expenditure of surgery & 12 & $5.6 \%$ & $11.9 \%$ \\
\hline & Total & 214 & $100.0 \%$ & $211.9 \%$ \\
\hline
\end{tabular}

Source : Primary Survey

The table 5.10 shown descriptive statistics of health expenditures. The study shows that monthly expenditure on medicines are the largest expenditure item, 1795 rupee per household on average. For those reporting expenditure greater than zero, the average amount that households' spend is 2375.24 rupee(see table.5.7). Turning to the different kinds of expenditure, the most common health expenditure are for medicines as one third of the households reported such expenditure. Only eleven households are spending anything on surgery. Among them, average monthly expenditure is 813 rupee. The hospital is another important expenditure of households. The households are spending on hospital fee on average 562 rupee per month. The minimum and maximum values of each health expenditure also derive from the table 5.10

Table 10

Descriptive Statistics of different expenditure

\begin{tabular}{|l|c|c|c|c|c|}
\hline & $\mathbf{N}$ & $\begin{array}{c}\text { Minimu } \\
\mathbf{m}\end{array}$ & $\begin{array}{c}\text { Maxim } \\
\mathbf{u m}\end{array}$ & Mean & Std. Deviation \\
\hline $\begin{array}{l}\text { Amount of hospital } \\
\text { fee }\end{array}$ & 101 & 150 & 4000 & 562 & 527.56070 \\
\hline Amount of surgery & 11 & 10000 & 15055 & 813 & 45281.94503 \\
\hline
\end{tabular}


International Journal of Social Science and Economic Research

ISSN: 2455-8834

Volume:06, Issue:07 "July 2021"

\begin{tabular}{|l|l|l|l|l|l|}
\hline Amount of medicine & 101 & 300 & 17000 & 1795 & 1923.96082 \\
\hline & & & & & \\
\hline
\end{tabular}

Source : Estimated based sample survey

\section{Determinants of household expenditure on health care}

The results of testing the hypothesis that households characteristics, income and expenditure, education affect the size of health care expenditure of households in the study area: In simple or multiple linear regression, the size of the coefficient for each independent variable gives you the size of the effect that variable is having on your dependent variable, and the sign on the coefficient (positive or negative) gives you the direction of the effect. In regression with a single independent variable, the coefficient tells you how much the dependent variable is expected to increase (if the coefficient is positive) or decrease (if the coefficient is negative) when that independent variable increases by one. In regression with multiple independent variables, the coefficient tells you how much the dependent variable is expected to increase when that independent variable increases by one, holding all the other independent variables constant. Remember to keep in mind the units which your variables are measured in.

Table 11

\section{Regression results}

\begin{tabular}{|l|c|l|l|ll|}
\hline Variables & coefficient & \multicolumn{1}{|c|}{ std. error } & t-ratio & \multicolumn{2}{|c|}{ p-value } \\
\hline Constant & 262.487 & 420.482 & 0.6243 & 0.5338 & \\
\hline $\begin{array}{l}\text { Expenditure on } \\
\text { food }\end{array}$ & 0.142586 & 0.00635918 & 22.42 & $000^{* * *}$ & \\
\hline Income & -0.04057 & 0.0102188 & -3.971 & 0.0001 & $* * *$ \\
\hline No. of elderly & 744.188 & 302.608 & 2.459 & $0.0155 \quad * *$ \\
\hline Family size & 292.974 & 75.1894 & -3.896 & $0.0002 \quad * * *$ \\
\hline No.of children & 283.239 & 153.976 & 1.840 & $0.0686 \quad *$ & \\
\hline education & -700.258 & 539.074 & -1.299 & 0.1967 & \\
\hline R-squared & 0.921011 & $\begin{array}{c}\text { Adjusted R- } \\
\text { squared }\end{array}$ & 0.916582 & & \\
\hline
\end{tabular}


International Journal of Social Science and Economic Research

ISSN: 2455-8834

Volume:06, Issue:07 "July 2021"

\begin{tabular}{|l|l|l|l|l|}
\hline F(7, 43) & 207.9362 & P-value(F) & 0.0027 & \\
\hline
\end{tabular}

$* * * 1 \%$ level of significance

** $5 \%$ level of significance

$* 10 \%$ level of significance

From the above regression of size of household health care expenditure on expenditure on food, income of households, number of elderly members, family size, number of children, education of household head in study area, it is observed that all independent variables except education have been found to have significant impact on the size households expenditure on health care.

The size of households expenditure on food items is the key determinant of health care utilization, have been found to have a significant positive impact on the size of health expenditure (at $1 \%$ significant level). The health care expenditure is to be expected to increase by 0.14 for each one rupee increase in food expenditure. This is because, health status is a negative function of food habits of household members.

Household income was found to be have a significant negative impact (at level 5\%) on the size of health care expenditure. The health care expenditure is expected to decrease by -0.04 for each one rupee increase in income of the households. Therefore, increase in income of households tend to decrease in health care expenditure.

Number of elderly members in Households were found a significant positive impact (at level $5 \%$ ) on the size of health care expenditure.

Family size found a significant negative impact (at level 1\%) on the size of health care expenditure.

Number of children in Households were found a significant positive impact (at level 10\% significant ) on the size of health care expenditure.

Interestingly education have a negative impact of health care expenditure in this analysis but it was found statistically insignificant because of its low $t$ value and high probability value.

The $\mathbf{R}^{2}=\mathbf{0 . 9 2}$, which explain the goodness of fit of the fitted regression. It shows that 92 percentage of variation in health care expenditure is explained by the variables that we were introduced in the model. 
International Journal of Social Science and Economic Research

ISSN: 2455-8834

Volume:06, Issue:07 "July 2021"

\section{Conclusion}

The study on the determinants of health care utilization shows that households are saddled with multiple health issues. While food expenditure, family size, number of elderly in the family, number of children have positive impact on health care expenditure, income and education have negative impact on health care expenditure. It drives home that these variables stubbornly influence health care utilization. The study, therefore, implies heightened allocation for health insurance as a deterrent against expenditure on health.

\section{REFERENCES}

Brijesh C. Purohit, \& Tasleem A. Siddiqui. (1994). Utilisation of Health Services in India. Economic and Political Weekly, 29(18), 1071-1080.

Donald S. Kenkel (1994) The demand for preventive medical care, Applied Economics, 26:4, 313-325.

Economic Review (1996, 2002, 2004, 2006). Kerala State Planning Board, Thiruvananthapuram.

Grossman, M. (1972). On the Concept of Health Capital and the Demand for Health. Journal of Political Economy, 80(2), 223-255.

Janet Currie, Jonathan Gruber, Health Insurance Eligibility, Utilization of Medical Care, and Child Health, The Quarterly Journal of Economics, Volume 111, Issue 2, May 1996, Pages 431466.

Kannan, K. (2005). Kerala's Turnaround in Growth: Role of Social Development, Remittances and Reform. Economic and Political Weekly, 40(6), 548-554.

Kutty, Raman V, P G K Panikar (1995). Impact of Fiscal Crisis on the Public Sector Healthcare System in Kerala: A Research Report. Thiruvananthapuram: Achutha Menon Centre for Healthcare System in Kerala.

Manning, W., Newhouse, J., Duan, N., Keeler, E., \& Leibowitz, A. (1987). Health Insurance and the Demand for Medical Care: Evidence from a Randomized Experiment. The American Economic Review, 77(3), 251-277.

Thomas, Eric J.; Studdert, David M.; Newhouse, Joseph P., et al. Costs of Medical Injuries in Utah and Colorado. Inquiry. 36:255-264, 1999. See also: Leape, et al., 1991. Brennan, et al., 1991. 